\title{
American Cutaneous Leishmaniasis unresponsive to antimonial drugs: successful treatment using combination of N-Methilglucamine Antimoniate plus Pentoxifylline
}

\author{
André Báfica ${ }^{\mathrm{I}, 2}$ MD, Fabiano Oliveira ${ }^{\mathrm{T}, 2}$ MD, Luiz A. R. Freitas ${ }^{\mathrm{I}, 2}$ MD, PhD, \\ Eliane G. Nascimento ${ }^{3}$ MSc and Aldina Barral ${ }^{1,2} \mathrm{MD}, \mathrm{PhD}$
}

\author{
${ }^{1}$ Faculdade de Medicina da Universidade \\ Federal da Bahia, ${ }^{2}$ Centro de Pesquisas \\ Gonçalo Moniz, FIOCRUZ, Bahia., ${ }^{3}$ Centro de \\ Referência em Doenças Endêmicas Pirajá da \\ Silva.

\section{Correspondence} \\ Aldina Barral CPqGM - FIOCRUZ/BA \\ Laboratório de Imunoparasitologia, \\ Rua Waldemar Falcão, 121 Brotas, \\ CEP: 40295-001., Salvador-Bahia - Brazil, \\ Phone/Fax: + 55713568782 (ext. 259) \\ E-mail: address: abarral@cpqgm.fiocruz.br
}

\begin{abstract}
Summary
Background American cutaneous leishmaniasis is characterized by single or multiple ulcerations. Cytokines, among other factors, have been shown to influence lesion development and tumoral necrosis factor-alpha is a major cytokine implicated in pathogenesis of ulcers. Observations We tested oral pentoxifylline, a known tumoral necrosis factor-alpha inhibitor, at doses of $400 \mathrm{mg}$ (2-3x/day), associated to $\mathrm{N}$-methylglucamine antimoniate $(15 \mathrm{mg} / \mathrm{kg} /$ day) in two patients with American cutaneous leishmaniasis unresponsive to antimonial drugs. We observed a satisfactory response with quick cure of skin lesions of these patients. Conclusions Our results suggest that oral pentoxifylline in association to $\mathrm{N}$-methylglucamine antimoniate should be consider in refractory cutaneous leishmaniasis patients.
\end{abstract}

\section{Introduction}

American cutaneous leishmaniasis (ACL) is a disease caused by protozoa of the genus Leishmania. It has a chronic clinical course, involving the skin and or mucous membranes exhibiting diverse clinical presentations. ACL represents a serious socio-economical problem, affecting the economically active population and especially, low-income groups. In endemic areas, it is responsible for the majority of hospitalizations due to dermatological problems ${ }^{\mathrm{I}}$.

Presently, the first-choice of treatment remains the pentavalent antimonials $\left(\mathrm{Sb}^{\mathrm{v}}\right)$, either $\mathrm{N}$-methylglucamine antimoniate or sodium stibogluconate. Others drugs, however, have been also used, such as pentamidine ${ }^{2}$ and amphotericin $\mathrm{B}^{3 \mathrm{a}}$ as second choice drugs or alopurinol ${ }^{2}$ or itraconazole ${ }^{4 \mathrm{a}}$ as alternative therapeutics.

TNF- $\alpha$ has been implicated in immuno the pathogenesis of ACL. It is expressed in lesions of patients with $\mathrm{ACL}^{3}$ and has been shown to be elevated in the serum of patients with mucocutaneous leishmaniasis, ${ }^{4,5}$ TNF- $\alpha$ has a potent mitogenic effect on fibroblasts, leading to collagen deposition and angiogenesis ${ }^{6}$. It induces an increase in collagenase production, leading to leukocyte sequestration and consequently a release of toxic metabolites by polymorphonuclear cells, an early step in chronic inflammation ${ }^{6}$. These mechanisms may arise in ACL patients with extensive ulcers leading to an important necrotic reaction.
Pentoxifylline, a synthetic xanthine derivative, is an hemorrheologic agent used in the treatment of peripheral vascular diseases but its mechanism(s) of action have not yet been fully elucidated ${ }^{7}$. It is known, however, that pentoxifylline inhibits the transcription of the tumoral necrosis factor- $\alpha$ (TNF- $\alpha$ ) gene $^{8}$ and potentiates the expression of inducible nitric oxide sinthase (iNOS) leading to nitric oxide (NO) production'.

Failure to respond to regular pentavalent antimonials treatment has been described in approximately I०\% of patients ${ }^{\mathrm{IO}}$. Pentoxifylline in association with $\mathrm{N}$-methylglucamine antimoniate proved to be a very efficient combination for treatment of refractory mucosal leishmaniasis ${ }^{\mathrm{II}}$ a disease associated with intense TNF- $\alpha$ production at lesion site and high serum TNF- $\alpha$ levels $^{4}$. Herein, we extend this observation to ACL reporting two cases of complete ulcer healing in $\mathrm{N}$-methylglucamine antimoniate's refractory ACL patients, after administration of oral pentoxifylline in addition to regular treatment.

\section{Case 1}

Patient I is a 49-year-old man, white, farmer, natural of Bahia - north east of Brazil (an endemic area of ACL). One month before seeking medical care, he presented a small ulcer in the distal third of the left leg associated with moderate local pain and left inguinal limphadenopathy. At examination, he had an $8 \times 4 \mathrm{~cm}$ single ulcer with infiltrated and elevated borders surrounding a necrotic center localized in left leg (Fig. IA). 

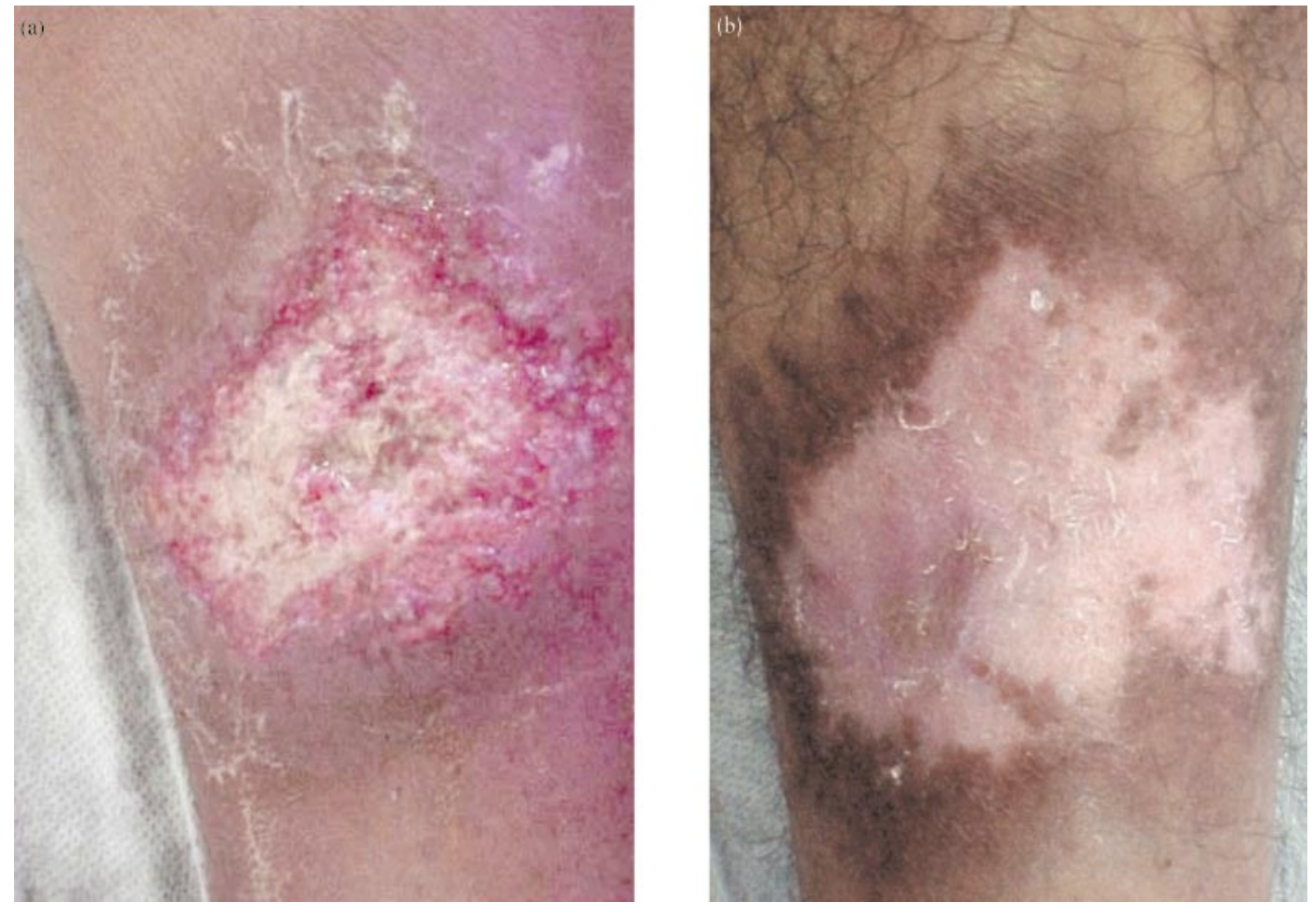

Figure 1 (a) extensive ulcer in the distal third of the left leg showing a necrotic weal and infiltrated borders. (b) 45 days after oral pentoxifylline/ $\mathrm{N}-$ methilglucamine antimoniante association showing complete healing of ulcer

The distal third of the left leg exhibited a strong erithematous reaction. The diagnosis of cutaneous leishmaniasis was confirmed based on a positive anti-Leishmania skin delayed type hypersensibility (DTH) and a positive anti-Leishmania immunofluorescent assay. Biopsy of the lesion revealed the presence of parasites and intense reactivity to TNF- $\alpha$ by immunohistochemistry. The patient was typed as having an infection by Leishmania braziliensis by polimerase chain reaction (PCR) of tissue sections ${ }^{\mathrm{I} 2}$. Treatment with intravenous $\mathrm{N}$-methylglucamine antimoniate was started ( $5 \mathrm{mg} \mathrm{Sb} / \mathrm{kg}$ / day during 20 days). One month later, the ulcer had increased in size $(8 \times 8 \mathrm{~cm})$ and the surrounding skin remained erithematous and painful. The patient received a second cycle of N-methylglucamine antimoniate (same dose) and 30 days after that a significant increase of ulcer size $(20 \times 8 \mathrm{~cm})$ associated to local edema and erithema was observed. A third cycle of pentavalent antimonial was given. Only a modest reduction of lesion size $(\mathrm{I} 8 \times 6 \mathrm{~cm})$ was observed one month after the 3 rd course of treatment, both the erithematous reaction and signs of disease activity were still visible. Since no side-effects of antimonial therapy were observed, the patient received a new cycle of the same drug (same dose) associated with oral pentoxifylline ( $400 \mathrm{mg}, 3 \mathrm{x} /$ day) during 20 days. A complete cicatrization of lesion was observed 45 days later with total re-epithelization and absence of erithema (Fig. IB). No side-effects were reported. Three months of follow-up showed a complete healing of lesion.

\section{Case 2}

Patient 2 is a 48 -years-old woman, white, and natural of Bahia, with a history of chronic cutaneous leishmaniasis ulcers, localized in left foot, since I993. In I994, a skin lesion biopsy showed the presence of Leishmania parasites. Treatment with $\mathrm{Sb}^{\mathrm{v}}$ was started and, during this period (I994-2000) she received about 470 ampoules of $\mathrm{Sb}^{\mathrm{v}}$ in regular cycles and appropriated dosages. Partial healing of lesions was observed, but never a complete cicatrization. She had a positive anti-Leishmania DTH and a positive anti-Leishmania serology (by IFA and ELISA - enzyme-linked immuno sorbent assay). In November of 2000 , at examination, she presented atypical ulcers in the left foot associated to intense local erithematous reaction and secondary bacterial infection 

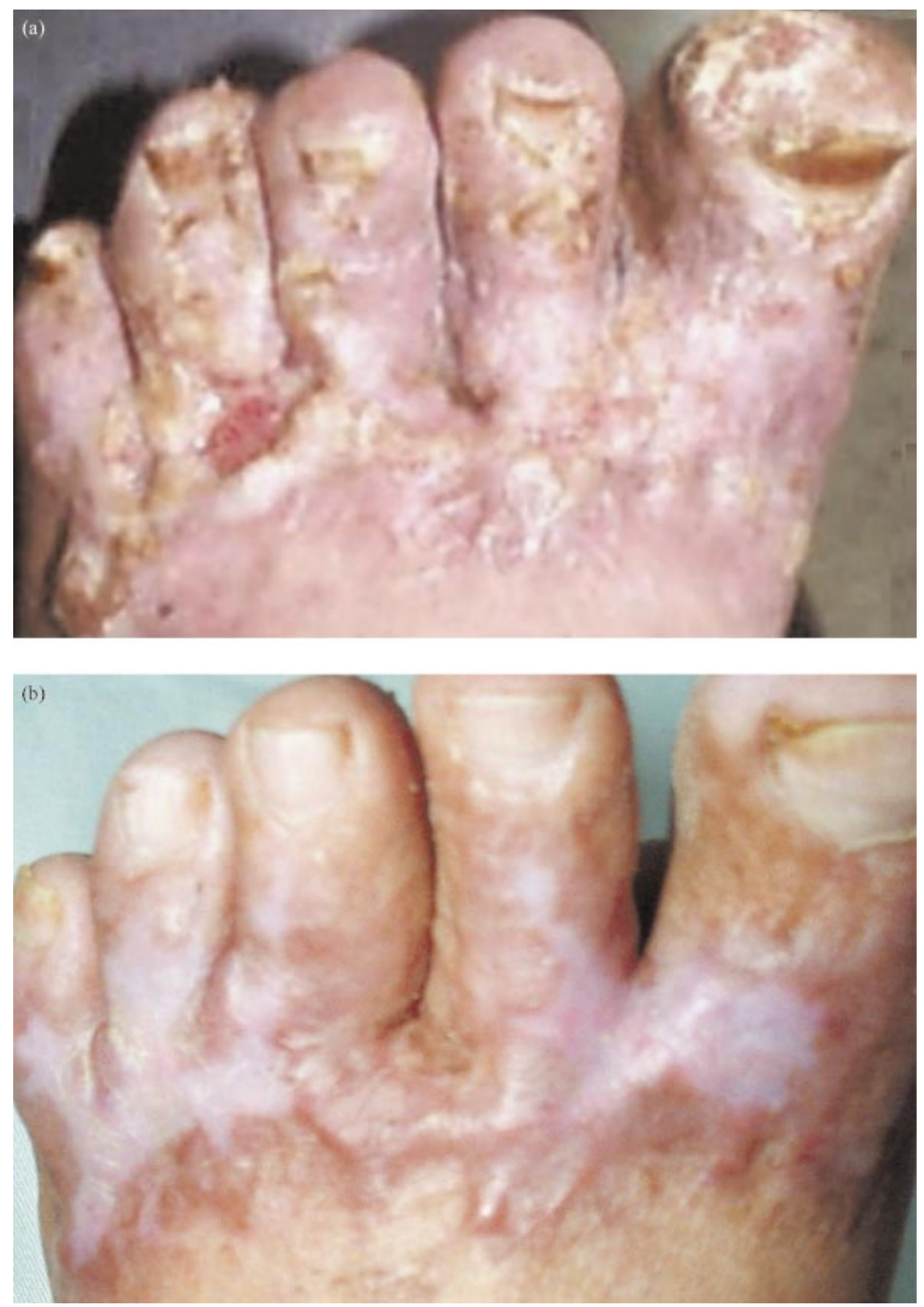

Figure 2 (a) atypical lesion associated with erithematous reaction and secondary bacteria infection. (b) 2 months after oral pentoxifylline/N-methilglucamine antimoniate association showing total healing of lesions

(Fig. 2A). The diagnostic of leishmaniasis was made after isolation of Leishmania parasites in culture medium and biopsy of the lesion revealed the presence of parasites and intense reactivity to TNF- $\alpha$ by immunohistochemistry. Oral pentoxifylline $800 \mathrm{mg} / \mathrm{day}$ associated with one cycle of $\mathrm{N}$ methylglucamine antimoniate (I $5 \mathrm{mg} /$ day/was introduced during 20 days). No side-effect was observed. One month later, she showed a moderate response with partial healing of ulcer and absence of erithematous reaction. Another cycle of pentoxifylline/ $\mathrm{Sb}^{\mathrm{v}}$ at the same dosage was given during Io days. One month later, she returned showing complete healing of foot lesions (Fig. 2B). 


\section{Commentary}

In Brazil, Io\% of ACL patients do not respond to $\mathrm{Sb}^{+3}$ therapy ${ }^{13}$. WHO classifies a primary patient as unresponsive when clinical or parasitological cure is absent at the end of first cycle $^{14}$. Herein, we show two cases of $\mathrm{Sb}^{+3}$ refractory cutaneous leishmaniasis patients: a man that did not respond to three cycles ( $\mathrm{I} 2 \mathrm{O}$ ampoules) of $\mathrm{N}$-methylglucamine antimoniate on usual dose and a woman that did not respond to various cycles. Both, demonstrated response with complete cicatrization of lesion when i.v. N-methylglucamine antimoniate (I $5 \mathrm{mg} \mathrm{kg}$ / day) was associated to oral pentoxifylline $(800-\mathrm{I} 200 \mathrm{mg} /$ day). The intense TNF- $\alpha$ expression demonstrated by immunohistochemistry can be collaborating for worst evolution of clinical picture of lesion. In contrast, low levels of TNF- $\alpha$ were found in the serum of these patients (Patient $\mathrm{I}=0 \mathrm{pg} / \mathrm{mL}$ and Patient $2=15,8 \mathrm{pg} / \mathrm{mL}$ ), suggesting that the immune response in cutaneous leishamaniasis is localized in the site of ulcer. TNF- $\alpha$ has been shown to participate in parasite killing ${ }^{15}$ but its overproduction may be responsible for tissue destruction and hence maintaining of the lesion.

Pentoxifylline has been shown to potentiate the beneficial effects of $\mathrm{N}$-methylglucamine antimoniate in human mucosal lesions ${ }^{\mathrm{II}}$. Recently, Lessa et al. showed that pentoxifylline/ antimony association was able to induce quick cure in 9 of Io patients with mucosal leishmaniasis refractory to antimony alone. TNF- $\alpha$ levels were significantly diminished after use of pentoxifylline ${ }^{\mathrm{II}}$. Moreover, pentoxifylline has been used in leprosy, a disease associated with enhanced production of TNF- $\alpha$, and lead to regression of inflammatory symptoms ${ }^{16}$. Accordingly, our findings show that pentoxifylline was able to decrease the inflammatory reaction and consequent tissue damage. We cannot rule out a possible vasodilatatory effect of the drug, allowing for access of defense mechanisms to the tissue inflamed. It is also possible that pentoxifylline induced activation of NO synthase and consequent Leishmania killing. The effect of pentoxifylline as an in vivo immunomodulator molecule remains to be demonstrated in humans.

These case reports show that pentoxifylline in association with $\mathrm{N}$-methilglucamine antimoniate therapy was able to induce quick healing in two patients with cutaneous leishmaniasis refractory to antimonial alone, suggesting the use of this association in patients that do not exhibit ulcer healing after standard therapy.

\section{Acknowledgments}

The authors thank Dr Manoel Barral-Netto for critical review of this manuscript; Dr Cláudia Brodskyn for cytokine assays, Dr Camila Indiani de Oliveira for provide the polimerase chain reaction of tissue sections and Dr Tania Correa for the immunostaining reactions. This study was supported by
CNPq, Pronex and PAPES/FIOCRUZ. Aldina Barral is senior investigator from $\mathrm{CNPq}$.

\section{References}

I Marsden PD, Sampaio RNR. Mucocutaneous leishmaniasis: a review of clinical aspects. An Soc Bras Med Trop I975; 4: 309-326.

2 Costa JML, Cunha AK, Gama MEA, Saldanha ACR. Diffuse cutaneous leishmaniasis in Brazil: a review. An Bras Dermatol I998; 73: 565-576.

3a Sampaio SAP, Castro RM, Dillon NL et al. Treatment of mucocutaneous (American) leishmaniasis with amphotericin B. report of 70 cases. Int J Dermatol I97 I; Io: I79-I 8 I.

3 Silva TMC, Barral A, Pompeo MML et al. In situ inflammatory immune response in human tegumentary leishmaniasis: morphologic evidence for a pathogenic role of TNF- $\alpha$. Mem Inst Oswaldo Cruz I998; 93: 49-50.

4a Albanese G, Giorgetti P, Santoagostinho L et al. Cutaneous leishmaniasis: treatment with itraconazole. Arch Dermatol I 989; I 25: I 540-I 542.

4 Blackwell JM. Tumor necrosis factor alpha and mucocutaneous leishmaniasis. Parasitol Today I999; I5: $73-75$.

5 Da-Cruz AM, de Oliveira MP, De Luca PM et al. Tumor necrosis factor-alpha in human american tegumentary leishmaniasis. Mem Inst Oswaldo Cruz I996; 91: 225-229.

6 Mirshahi S, Soria J, Mirshahi M et al. Expression of elastase and fibrin in venous leg ulcer biopsies: a pilot study of pentoxifylline versus placebo. J Cardiovasc Pharmacol I995; 25: IOI-IO5.

7 Aviado DM, Dettelbach HR. Pharmacology of pentoxifylline a hemorrheologic agent for the trea tment of intermittent claudication. Angiology; I984; 35: 407-4I7.

8 Doherty GM, Jensen JC, Alexander HR et al. Pentoxifylline suppression of tumor necrosis factor gene transcription. Surgery I99I; IIO: I92-I98.

9 Hoebe KH, Gonzalez-Ramon N, Nijmeijer SM et al. Differential effects of pentoxifylline on the hepatic inflammatory response in porcine liver cell cultures. Increase in inducible nitric oxide synthase expression. Biochem Pharmacol 200I; 6I: II37-II44.

Io Koff AB, Rosen T. Treatment of cutaneous leishmaniasis. J Am Ac Dermatol I994; 3I: 693-708.

i I Lessa H, Machado P, Lima F et al. Successful trea tment of refractory mucosal leishmaniasis with pentoxifylline plus antimony. Am J Trop Med Hyg 200I; 65: 87-89.

I2 Harris E, Kropp G, Belli A et al. Single-step multiplex PCR assay for characterization of new world Leishmania complexes. J Clin Microbiol I989; 36: I989-1995.

I3 Mendonça SC, Coutinho SG, Amendoeira RR et al. Human american cutaneous leishmaniasis (Leishmania b. braziliensis) in Brazil: lymphoproliferative responses and 
influence of therapy. Clin Exp Immunol I986 May; 64: 269-276.

I4 WHO. Control of Leishmaniases-Report of a WHO Expert Committee, 1990.

I 5 Ribeiro de Jesus A, Almeida RP, Lessa $\mathrm{H}$ et al. Cytokine profile and pathology in human leishmaniasis. Braz J Med Biol Res I998; 3I: I43-I48.

I6 Nery JA, Perisse AR, Sales AM et al. The use of pentoxifylline in the treatment of type 2 reactional episodes in leprosy. Indian J Lepr 2000; 72: 457-467. 